\title{
Extramedullary Hematopoiesis in Murine Schistosomiasis Mansoni
}

\author{
HL Lenzi ${ }^{+}$, JA Lenzi, FC Rosman, M Pelajo-Machado, EM Mota, MS Panasco, \\ DN Oliveira
}

Departamento de Patologia, Instituto Oswaldo Cruz, Av. Brasil 4365, 21045-900 Rio de Janeiro, RJ, Brasil

During Schistosoma mansoni infection, there is morphological evidence of involvement of various hematopoietic growth factors, which cause eosinophil, neutrophil, megakarvocytic and ervthroid extramedullary foci in the liver, lymph nodes and omental and mesenteric milky spots. While the eosinophil metaplasia in the periphery of hepatic granulomas roughlv reproduced the intensity of the medullary eosinopoiesis, the neutrophil metaplasia, on the contrary, was more intense during the period of neutrophil depression in the bone marrow. This fact suggests that extramedullary hematopoietic foci are locally regulated, and amplify and or compensate the svstemic hematopoietic response during the infection.

Key words : eosinophil - ncutrophil - megakaryocyle - hematopoiesis - Schistosoma mansoni - lymph nodes milky spots

Schistosoma mansoni infection in mice and humans, duc to deposition of eggs in host tissues and systemic and local release of antigens, causes a very complex sequence of events, changing the behavior of eosinophil, neutrophil, monocytic. megakaryocytic, lymphocytic and erythroid series inside the bone marrow (Lenzi et al. 1987, Lenzi 1991). However, in mice and hamsters infected with $S$. mansoni or $S$. japonicum, extramedullary islands of eosinophil precursors regularly occur in the liver, colonic mesenteries, and mesenteric lymph nodes (Byram et al. 1978, Borojevic et al. 1981). In this study we showed the time of occurence and the different places where extramedullary hematopoicsis were detected during schistosome infections. We also related the intensity of hopatic perigranulomatous mycloid metaplasia with the medullary myelopoiesis.

Swiss Webster mice of both sexes were studied on days $15,20,25,30,35,40,45,50,55,60,70$, $80,90,100,110,120$ and 160 after infection. The animals were infected when they were five days old by percutaneous exposure to 70 cercariae of the Belo Horizonte strain of $S$. mansoni. Six animals were sacrificed each day, together with the same number of matched controls. Femoral bone marrow cells were isolated by a modification of the method described by van Furth and Cohn (1968), cytocentrifuged and stained with Giemsa-

Research supported by CNPq (No. 50.0320-90.0) and FIOCRUZ

+. Corresponding author
Glycinè (Lenzi 1991). Absolute eosinophil and total nucleated cells counts were carricd out using Discomb's fluid in Fuchs-Rosenthal and Turk's fluid in Neubauer chambers, respectively. The total number of medullary neutrophils was figured out based on the percentage of each lineage in the cytocentrifuged slides. and the total cell counting in the Neubauer chamber. Samples were taken from the liver, intestines, pancreas, lungs. spleen, lymph nodes and mesentery, fixcd in Millonig formalin, and embedded in paraffin. Sections were stained with hematoxilin and cosin. Lennert's Giemsa and Gomori's silver reticulin stains. To quantify the number of hepatic granulomas presenting myeloid metaplasia foci, ten of them. stained with Lennert's Gicmsa, were studicd. For electron microscopic examination, liver sections were fixed in $2.5 \%$ glutaraldeyde buffered with $0.1 \mathrm{M}$ cacodylate and postfixed in $1 \%$ osmium tetroxide. dehydrated in graded acetone series and cmbedded in epoxy resin. Ultra-thin sections were stained with uranyl acctate and lead citrate and observed by an EMS 10 B Zciss electron microscope.

The most precocious finding was an increase in splenic eosinopoiesis, erythropoicsis, megakaryopoiesis and neutropoiesis that was verified on the 25th day of infection. Foci of extragranulomatous metaplasia characterized by immature myeloid cells in portal space (Fig. 3-C), sinusoids (Fig. 3-A) and close to the capsule were detected between 30 and 35 days after infection. Extramedullary eosinophilic granulocytopoicsis occurred in the periphery of hepatic schistosomal granulomas from the 40th day on, attaining maxi- 

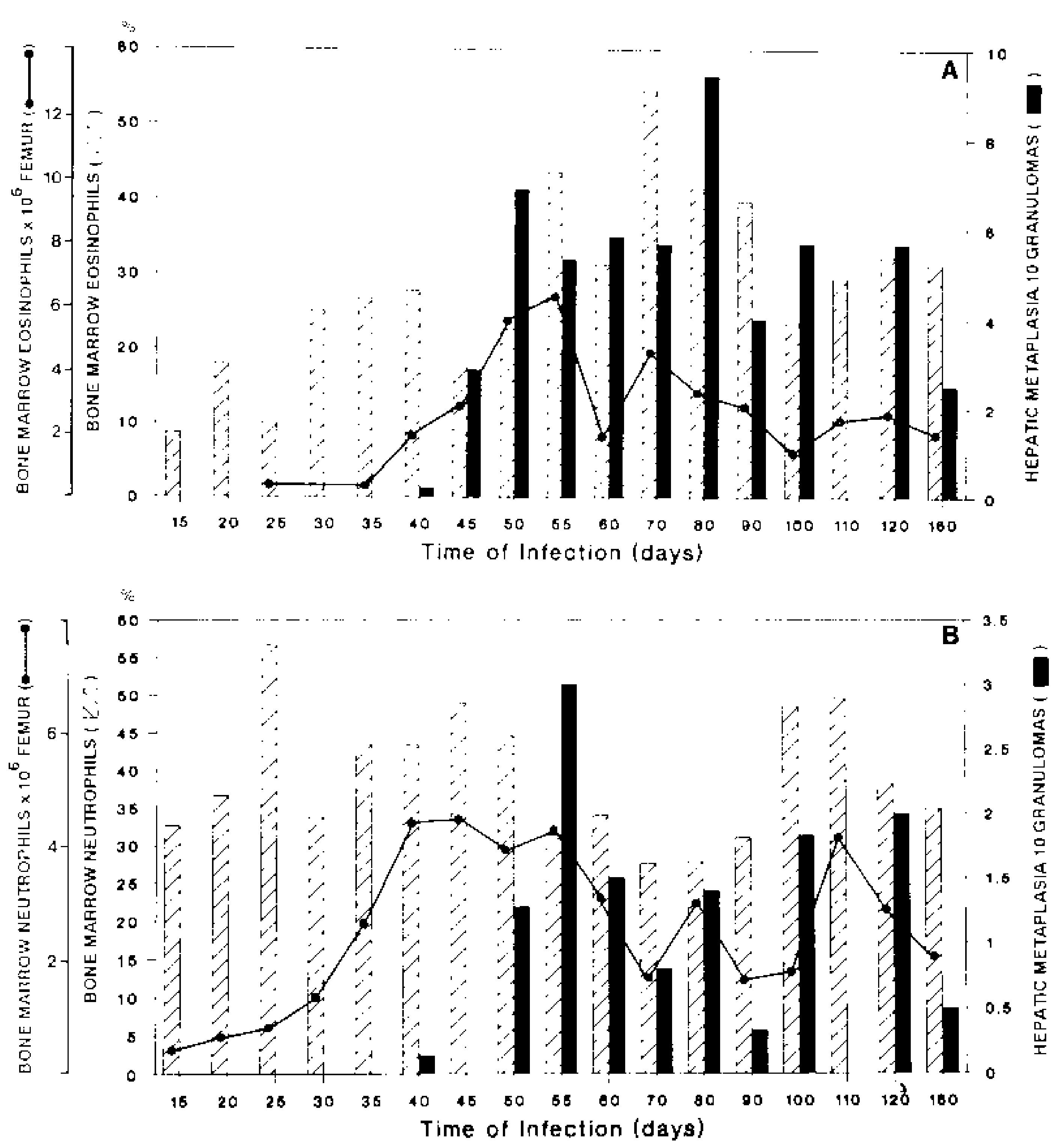

Fig. 1: comparison between eosinophil (A) and neutrophil (B) metaplasia in the liver and eosinopoiesis and neutropotesis in the bone martow during Schistosoma mansoni infection.

mum intensity on the 80th day after infection, persisting until the end of the experiment (Fig. 1-A). Peri-granulomatous neutrophil metaplasia also appeared from the 40th day onward, but it was more intense on the 55th day of infection. While the cosinophil metaplasia roughly reproduced the intensity of the medullary cosinopoiesis. the neutrophil metaplasia, on the contrary, was more intense during the period of neutrophil depression in the bone marrow (Fig. 1-B). The myeloid foci were composed by promyelocytes, myelocytes. metamyclocytes and more mature cosinophil or neutrophil granulocytes (Figs 2, 3, 6-A.B). The myeloid foci or nests were localized in the periphery of the granulomas (cxternal zone) and the cells were in direct contact with hepatocytes and intermixed with or surrounded by reticular and type III collagen fibers (Fig. 4). With the advancing of the infection, the metaplasic foci exhibited a predominance of mature cells over blast cells. Macrophages rich in schistosome pigment were often found in the middle of perigranulomatous cellular metaplasia (Fig. 3-D). Omental and mesenteric milky spots and lymph nodes mainly from mesentery and renal hilus presented, very often. extramedullary hematopoiesis. expressing eosinophil, and. eventually, neutrophil, megakariocytic and erythroid cells (Figs 5, 6-C). Myeloid metaplasia was not found in control mice and in the intestinal and pancreatic granulomas of the infected group. Only in a single case, with 160 days of infection, one pulmonary granuloma showed cosinophil metaplasia.

The organ dependency can be due to local capacity to produce hemopoietic growth factors and reproduce hemopoictic inductive microenvironment (Jenkins et al. 1972). Though a wide variety of murine cell types have been shown to produce specific hemopoietic growth factor mRNAs and bioactivitics in vitro (Nicola 1989). little is known about the sites of their production in vivo (Troutt \& Lee 1989). Granulocyte-macrophage (GM) and Granulocyte (G) colony stimulating factors (CSF) activities have been partially characterized in a varicty of mouse tissues. However, definitive evidence at the molecular level for their in vivo production in these tissues has been lacking (Troutt \& Lee 1989). For cxample, Chan et al. (1986) have shown no evidence of GM-CSF mRNA production in any of 57 human tissue samples tested. In 
contrast. M-CSF mRNA has been found in all murine tissues tested except for intestine (Rajavashisth el al. 1987). This fact can explain the lack of hemopoictic foci in intestinal granulomas. suggesting that induced transcription of hemopoictic growth faclor genes is involved in win in the host response to infection, and that the pro- duction of some of these factors may be compartmentalized in the organism (Trout1 \& Lee 1989).

Probably, during schistosomal infection there is supply of bonc marrow-derived cells to various tissues. The finding of immature myeloid cells within the hepatic sinusoids (Fig. 3-A) before the occurrence of perigranulomatous cosinophil meta-
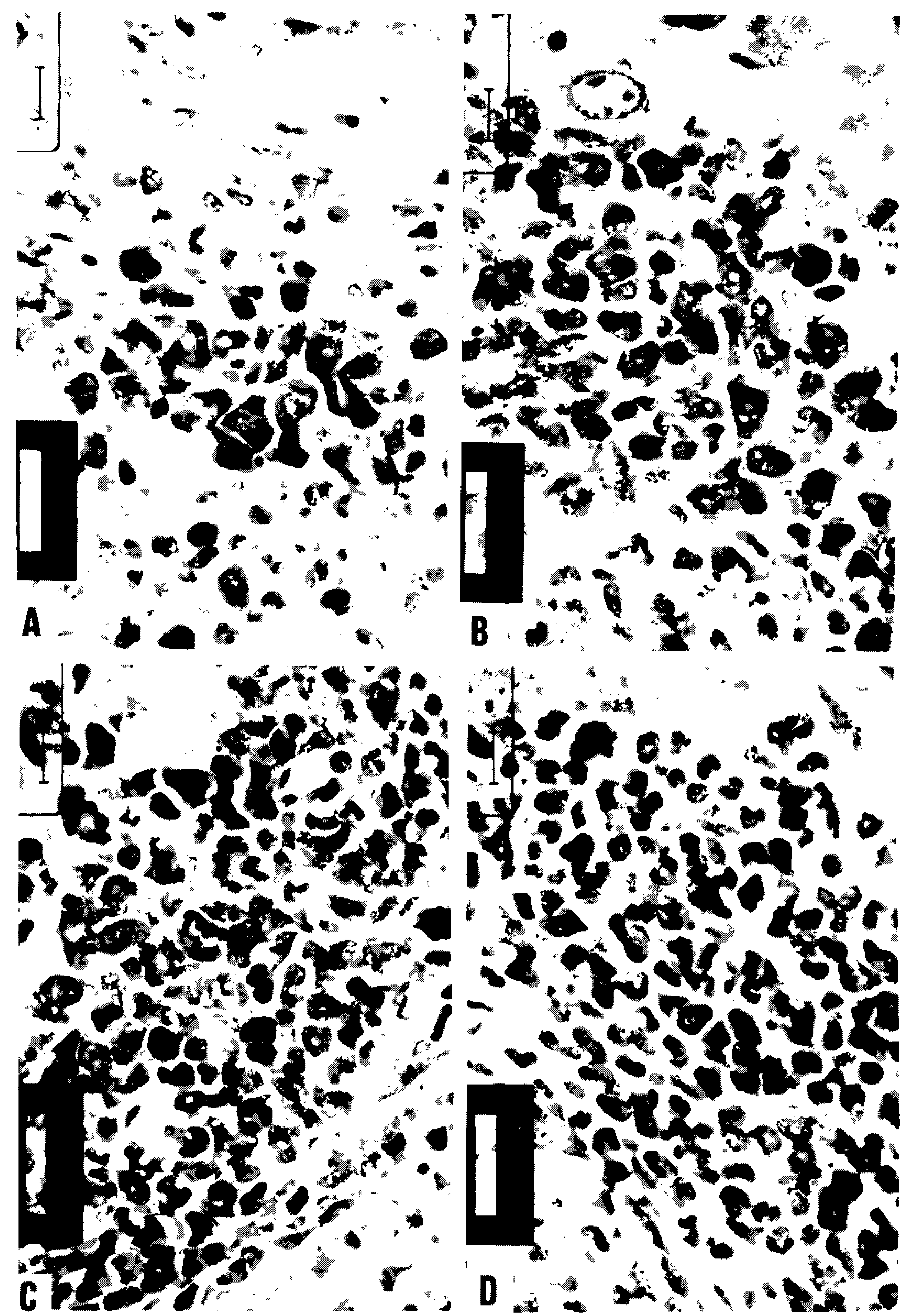

Fig. 2: perigranulomatous myeloid metaplasia toci in hepatic granulomas. in different stages of maturation (A-D), showing promyelocytes, myelosytes, metamyelocytes and mature eosinophuls. (I ennert's (jiemsa. X 1000 ). 
plasia. suggests the exogenous origin of the eosinophil precursors. as was also obsened by Borojevic et al (1981). Clark et al (1988) proposed that granuloma macrophages are supplied bu both bone marrow-dersed and focally produced mono- crles in S. monsomi-infected mice. The relative contributions of these two sources to the monocyte supply are subject to change as the vigorous granulomatous response undergoes immunologic down modulation. It has been shown that cells

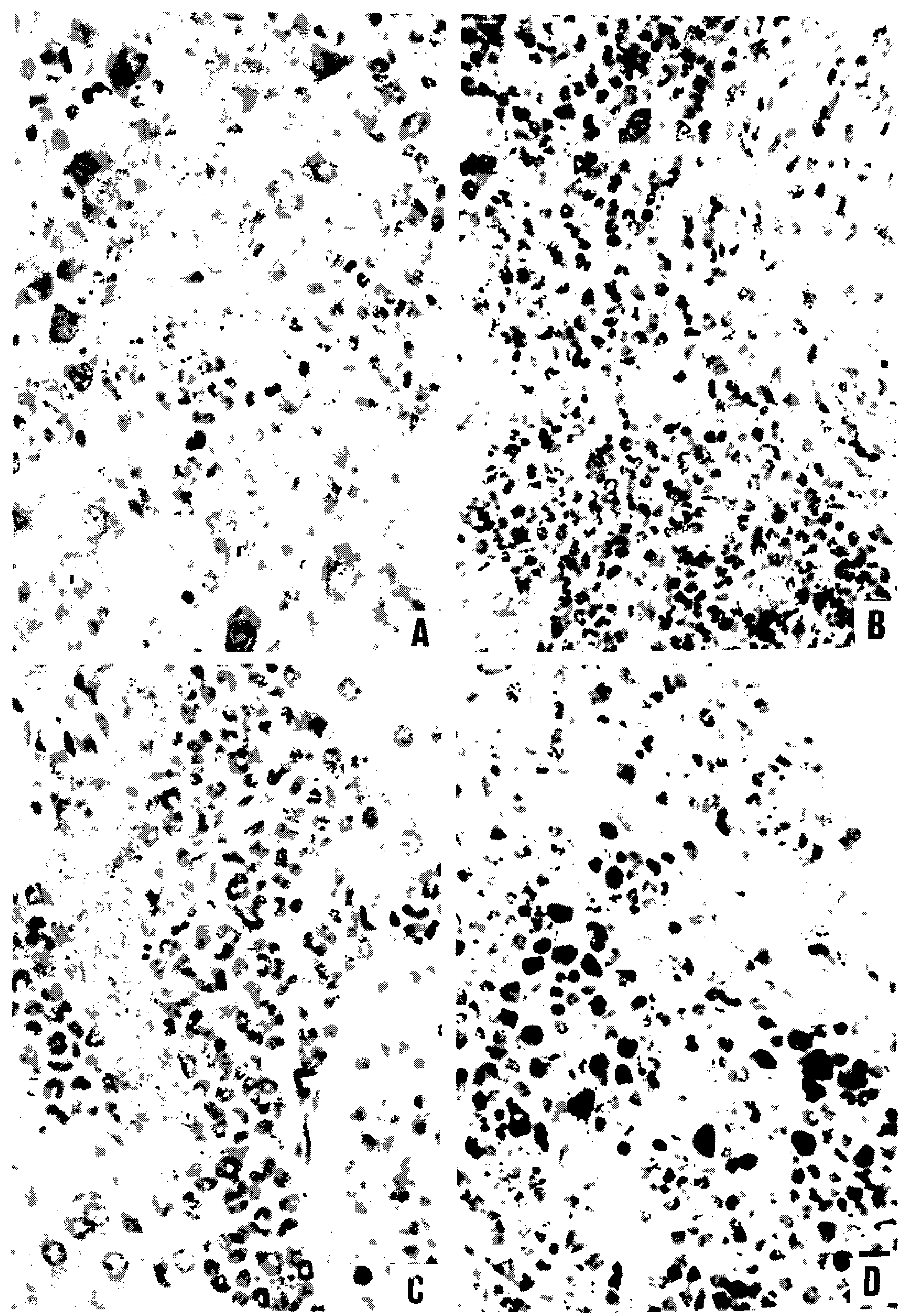

Fig. 3: intrasimusoidal (A) and perigranulonatous (IB) neutrophil metaplasia, and portal cosinophil metaplasia close to biliary duct (C). Matrophages with schistosomal pigment and plasmoryles and perigranulomatous eosinophil metaplasic focus (D). (A: lennert`s Giemsa. X 400 (55 days of inliction). 13: I emert's (jicmsa. X 400 (70 days of infection). C: H\& X X 500 (30 days of infution). D l connert's (siemsa. $X 500$ ( 80 days ol indection) 
capable of division and differentiation do circulate normally in peripheral mice blood. Goodman and Hodgson (1962) showed clearly that normal peripheral leukocytes from F1 hybrid mice can be transplanted and proliferate in lethally irradiated parent or closcly related homologous strain animals to promote survival and to give rise to lymphopoiesis. granulopoicsis and erythropoiesis of donnor type. Butterfield et al. (1982) demonstrated that cosinophil colonies developed mainly from
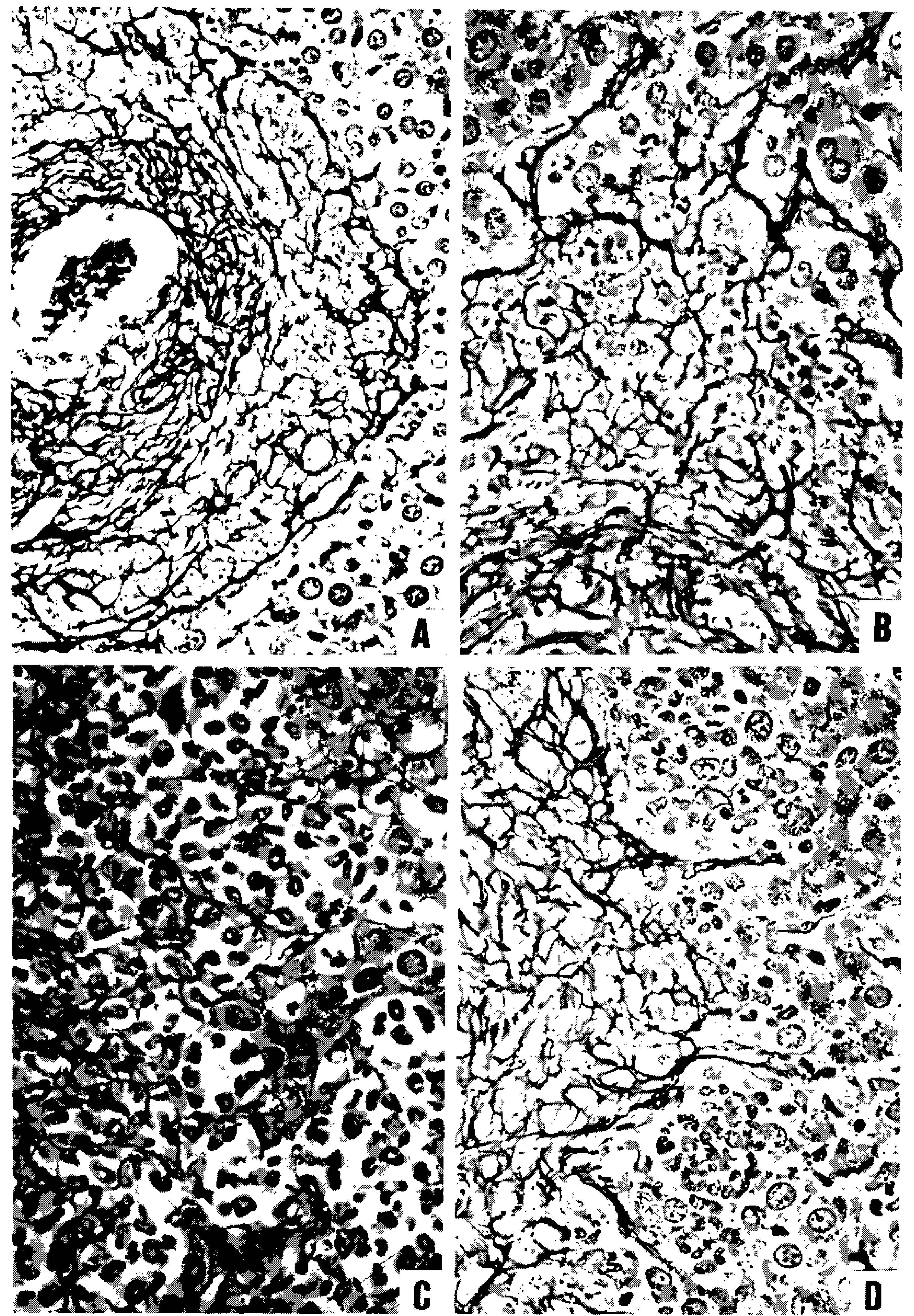

Fig. 4: reticular fibers in the peripheric zone of hepatic granulomas, forming a delicate stromal mesh in myeloid metaplastic areas $(\Lambda, B)$. Intrasinusoidal and perigranulomatous myeloid metaplasic foci, surrounded by reticular fibers (C). Myeloid metaplastic foci in the interface between granuloma stroma and hepatocytes (D). (Gomori's reticulum. X 400 A, B - 60 days of infection. C, D - 55 days of unfection). 
nonrosetting, null cell population. Eosinophil-Colony Forming Cell (Eo-CFC) lacked the human Tcell marker Leu 1, but demonstrated the human B-cell marker. HLA-DR. Eo-CFC was also present in peripheral blood and possessed properties similar to those in the bone marrow. These fact may explain the hemopoietic cells seeding in tissues of hemopoietic potential. such as lymph nodes. milky spots and liver granulomas.

The selective stimulation of eosinophils, neutrophils and, maybe, monocytic series in the periphery of hepatic granulomas could be achieved

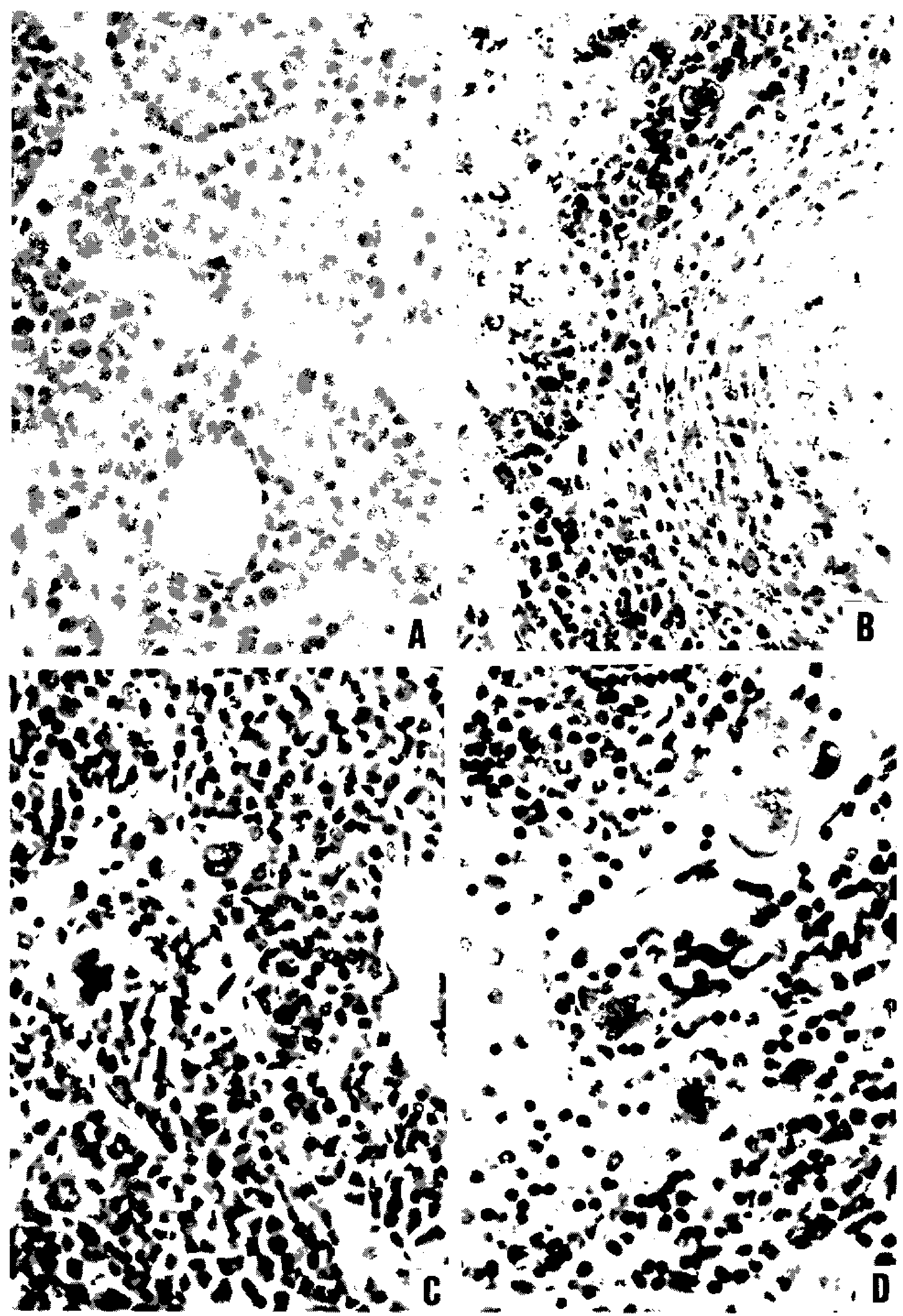

Fig. 5: eosinophil metaplasia in medullary cords of renal hylus lymph nodes $(\Lambda)$, sometimes associated with a megakaryopoiesis (C, D). Perigranulomatous eosinophil metaplasia, with mactophages, plasmocytes and megakaryocyte. (A: H\&E. X 500 (40 days of infection). B: Lennert's Giemsa. X 310 (70 days of infection). C: H\&E. X 400 (70 days of infection). D: H\&E. X 500 (120 days of infection). 
either by progenitor selection or through specific stimulation of less differentiated stem cells (Borojevic et al. 1981). Schistosomal granulomas are composed by cells that are potential producers of hemopoictic growth factors. such as lymphocytes, macrophages, fibroblasts, mast cells and endothelial cells ( Broudy et al. 1986. Clark et al. 1988, Zsebo et al. 1988, Nicola 1989). Borojevic et al. (1981) considered the Kupffer cell stimulation and hiperplasia responsible for this extramedullary granulocytopoicsis. Borojevic et al. (1985) observed that intraperitoneal glass implants in mice with chronic $S$. mansoni infection induce intense local mycloid reactions involving essentially myeloid granulocytes. An association of myelopoiesis with differentiated macrophages mobilized on glass implants and with dense ameboid cells located inside myeloid foci was detected. A macrophagc-dependent induction of this eosinophil reaction was postulated. An augmentation of the mutual interaction of T cells and macrophages by GM-CSF is one of the important mechanisms of eosinophil-rich granuloma formation in S. japonicum (Owhashi et al. 1987).

The simultaneous occurrence of hemopoietic foci in different organs suggests that during murine schistosomal infection, stimulating common factors are acting systematically in various sites at the same time. or they are locally produced by similar stimulants. Actually. the levels of bonemarrow and perigranulomatous eosinopoiesis showed here followed the same kinetics of splenic
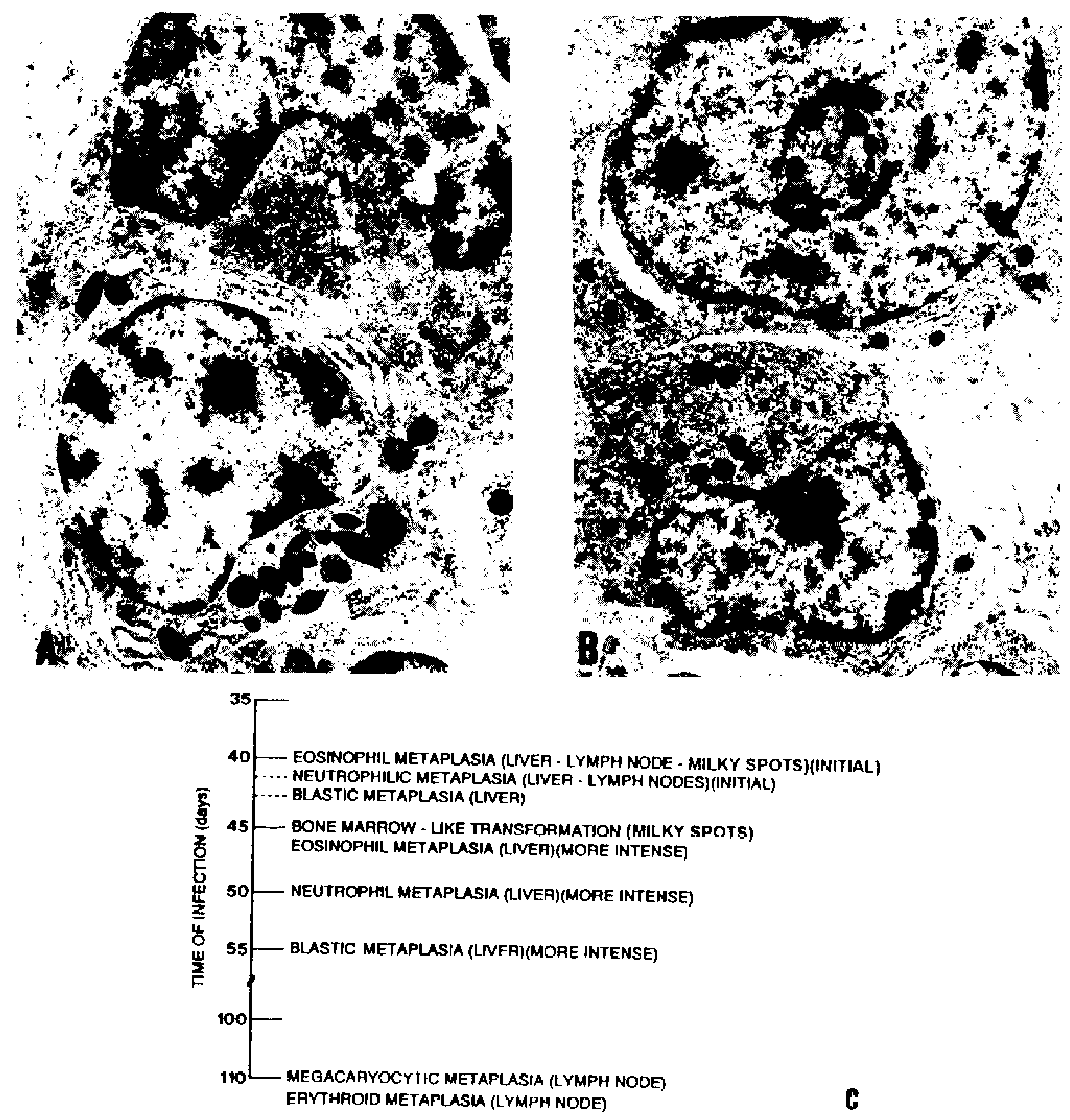

Fig. $6 \mathrm{~A} \mathrm{~B}$ : eosinophil peri-granulomatous metaplasia in the liver. Eosinophil promyelocyte in contact with monocyte $(\mathrm{A})$ : eosinophil promyelocyte and myelocyte with ring-shaped nucleus (B): $(A 7000 \mathrm{X}$ B $5500 \mathrm{X})$. (C): extramedullary hematopoiesis during Schistosoma mansoni infection. Time of appearance and sites of metaplasic loci. 
lymphocyte interleukin-5 response (Th2 dependent) described by Grzych et al. (1991) in the same infection.

Homing of progenitor cells can be conceived as a two-step phenomenon: first. progenitor cells arriving from bone marrow must be recognized by and interact with the luminal surface of endothelium; second the progenitor cells must be recognized by and bind to lincage-specific stromal cells that support their proliferation and maturation. Extracellular matrix components can take part in this phenomenon. For instance, it has been shown that one class of proteoglycans, heparan sulfate, can selectively cxtract and bind hematopoietic growth factors, presumably presenting them to progenitor cells (Roberts et al. 1988). Another fairly well-defined protein called haemonectin has been shown to be involved in the lincage specific binding of granulocytic precursors during both posinatal and fetal development (Campbell et al. 1987). Junqueira et al. (1986) demonstrated that glycosaminoglycan content was increased in schistosome granulomas. and we observed a topographical relationship between the connective tissue and the perigranulomatous cosinophil foci (Fig. 4).

Our findings indicate that, during schistosome infection. there is morphological evidence of involvement of various hematopoietic growth factors, which act in different sites, specially around the hepatic granulomas, and in lymph nodes and milky spots, causing extramedullary hematopoicsis. The hematopoictic foci appeared to be locally regulated. and amplify and/or compensate the systemic or bone marrow hematopoietic response caused by a huge antigen release by the parasites during the infection.

\section{ACKNOWLEDGMENTS}

To AS Rodrigues, FF Cruz, H Ferreira. ID Pedro, LFG Caputo and VC Valentin for technical assistance and to HMN Diniz, GJ Vieira, JC Cruz and VCR Sá for preparing the figures.

\section{REFERENCES}

Borojevic R, Nicola MH, Santos-da-Silva C, Grimaldi Jr G 1985. Schistosoma mansoni: extramedullar eosinophil myelopoiesis induced by intraperitoncal glass implants in chronically infected mice. Exp Parasitol 59: 290-299.

Borojevic R, Stocker S, Grimaud JA 1981. Hepatic eosinophil granulocytopoiesis in murine experimental schistossomiasis mansoni. Br J Exp Pathol 62: 480489.

Broudy VC, Kaushansky K, Segal GM, Harlan JM, Adamson JW 1986. Tumor necrosis factor type alfa stimulates human endothelial cells to produce granulocyte/macrophage colony-stimulating factor. Proc Natl Acad Sci USA 83: 7467-7471.
Butterfield JH, Fisenbrey AB, Gleich GJ 1982. Membrane marker characterization of the eosinophil colony-forming cell. Br J Haematol 51: 209-216.

Byram JE, Imohiosen liAF, von Lichtenberg F 1978. Tissue eosinophil proliferation and maturation in Schistosome-infected mice and hamsters. Am J Trop Med IIvg 27: 267-270.

Campell AD, Long MW, Wicha MS 1987. Haemonectin, a bone marrow adhesion protein specific for cells of granulocyte lineage. Nature 329: 744 746.

Chan JY, Slamon DJ, Nimer SD. Golde DW, Gasson JC 1986. Regulation of expression of human granulocyte/macrofage colony-stimulating factor. Proc Natl Acad Sci USA 83: 8669-8673.

Clark CR, Chen BDM, Boros DL, 1988. Macrophage progenitor cell and colony-stimulating factor production during granulomatous schistosomiasis mansoni in mice. Inf Immunity 56: 2680-2685.

Goodman JW, Hodgson GS 1962. Evidence for stem cells in the peripheral blood of mice. Blood 19:702714.

Grzych JW, Pearce L, Cheever A. Caulada ZA, Caspar $P$, Heiny $S$, Lewis F, Sher A 1991. Egg deposition is the major stimulus for the production of Th2 cytokines in murine schistosomiasis mansoni. $J$ Immunol 146: 1322-1327.

Jenkins VK. Trentin JJ, Speirs RS, MeGarry MP 1972. Hematopoictic Colony Studies. VI. Increased cosinophil-containing colonies obtained by antigen pretreatment of irradiated mice reconstituted with bonc marrow cells. $J$ Cell Physiol 79: 413-422.

Junqueira LCU. Montes GS, Toledo OMS, Joazeiro PP 1986. Morphological, histochemical and biochemical observations on the connective tissue matrix of in situ and isolated hepatic granulomas in experimental murine schistosomiasis. Ann Trop Med Parasitol 80:27-41.

Lenzi HL 1991. A dinâmica da resposta hematológica e celular na esquistossomose mansônica murina, com ênfase nas séries eosinofilica e mastocitária. Doctoral Thesis. Universidade Federal de Minas Gerais, Brazil, $580 \mathrm{pp}$.

Lenzi HI, Sobral ACL, Lenzi JA 1987. "In vivo" kinetics of eosinophils and mast cells in experimental murine schistosomiasis. Mem Inst Oswaldo Cruz 82 (Suppl.IV): 67-76.

Nicola NA 1989. Hemopoietic cell growth factors and their receptors. Annu Rev Biochem 58: 45-47.

Owhashi M, Maruyama H, Nawa Y 1987. Granulocyte-macrophage colony-stimulating factor enhances the production of eosinophil chemotactic lymphokine by egg-associated granulomas of Schistosoma japonicum-infected mice. Infect Immun 55: 2042-2046.

Rajavashisth TB, Eng R. Shadduck RK, Waheed A, BenAvram CM, Shively JE, Lusis AJ 1987. Cloning and tissuc-specific expression of mouse macrophage colony-stimulating factor mRNA. Proc Natl Acad Sci USA Biochem 84: 1157-1161.

Roberts R, Gallagher J, Spooncer E, Allen TD, Bloomfield F, Dexter TM 1988. Heparan sulphate bound growth factors: a mechanism for stromal cell mediated haemopoiesis. Nature 332: 376-378 
Troutt $\mathrm{AB}$, Lee F 1989. Tissue distribution of murine hemopoietic growth factor mRNA production. $J$ Cell Physiol 138: 38-44.

Van Furth $R$, Cohn $Z \wedge 1968$. The origin and kinetics of mononuclear phagocytes. JExp Med 128: 415-433.
Zsebo KM, Yuschenkoff VN, Schiffer $S$, Chang D, McCall E. Dinarello CA. Brown MA, Altrock BC, Bagby Jr GC 1988. Vascular endothelial cells and granulopoiesis: Interlcukin-l estimulates release of G-CSF and GM-CSF Blood 71: 99-103. 